\title{
Epidemiology of systemic pneumococcal infections in western Europe
}

J Gaillat MD

$I^{n}$ n no European country is pneumococcal infection, including meningitis, a notifiable disease. Therefore, there are no overall data regarding pneumococcal infection; the data that are available are scattered and come mainly from the northern European countries and France. Most are from national reference centres (Réseaux National de Santé Publique [EPIBAC], Saint Maurice, France; the Public Health Laboratory Service Communicable Disease Surveillance Centre, London, United Kingdom; the National Public Health Institute, Helsinki, Finland; the World Health Organization Collaborating Center for Reference and Research on pneumococci, Coppenhagen, Denmark and the Swedish Institute for Infectious Disease Control, Stockholm, Sweden) and are drawn from voluntary reports. Others are the results of limited and frequently cooperative studies. The shortage of clinical data contrasts sharply with the large amount of data on the epidemiology of resistance.

\section{CLINICAL EPIDEMIOLOGY}

Invasive infections: Table 1 (1-7) summarizes variations in incidence of invasive pneumococcal disease per 100,000 inhabitants by country and partially by year. Except for the low values in 1997 in Sweden (3), the average rate is approximately 10/100,000 inhabitants. The average rate masks a significant increase in incidence in Denmark from 1992 (9).

Table $2(1,2,4,5,7-10)$ reveals the variation in the incidence of pneumococcal septicemia by age. The incidence is bimodal, with one peak before two or five years of age, depending on the series, and another in persons 65 years of age and older, with a gradual increase after age 65 years - for example, the incidence is $70 / 100,000$ in adults older than 85 years in France (Figure 1). The Finnish data on children younger than age 16 show a growing increase in the incidence rate between
TABLE 1

Incidence of invasive pneumococcal disease per 100,000 inhabitants determined by blood culture, cerebrospinal fluid culture and other methods

\begin{tabular}{lcc}
\hline $\begin{array}{l}\text { Country, time period } \\
\text { (reference) }\end{array}$ & Overall incidence & Vaccine coverage \\
\hline Denmark, 1989 to $1994(1)$ & 10 to 19 & $84 \%$ \\
Sweden, 1964 to $1980(2)$ & 7.5 & - \\
Sweden, 1987 (septicemia) & 3.2 & $96.7 \%$ \\
and 1990 (3) & 10.2 & $95 \%$ \\
Finland, 1983 to $1992(4)$ & 9.1 & $84 \%$ to $89.5 \%$ \\
France, 1991 to $1996(15)$ & 8 to 10.6 & $95 \%$ \\
England and Wales (7) & 9.3 & \\
\hline
\end{tabular}

1983 and 1994 from 53/100,000 before age two years to $110 / 100,000$ with no rational explanation (9).

Fedson et al (11), in a forthcoming article, report a significant increase in pneumococcal incidence rates in 1996 $47 / 100,000$ in Sweden, $80 / 100,000$ in Denmark and $62 / 100,000$ in Norway (personal communication). This corresponds to published rates in North America. Despite comparable collection techniques, the same trend is not reported in France, where the rate has been stable since 1991 (Figure 2). In Sweden, opinions are divided. Some believe that there is an actual increase (12), while others believe the increase has been artificially created by a spontaneous increase in strains sent to the reference centres (13), especially because penicillin-resistant strains are more common (7).

Table 3 shows the incidence of pneumococcal meningitis by country. The incidence rates are even more similar between them from one country to another - around $1 / 100,000$ cases

Service de médecine interne et des maladies infectieuses, Centre Hospitalier de La Région Annécienne, Annecy, France

Correspondence: Dr J Gaillat, Service de médecine interne et des maladies infectieuses, Centre Hospitalier de La Région Annécienne, 74011 Annecy Cedex, France. Telephone 011-33-4-50-88-33-03, fax 011-33-4-50-52-73-88, e-mail smi.jgaillat@ch-annecy.fi. 
TABLE 2

Incidence of pneumococcal septicemia per 100,000 inhabitants by age

\begin{tabular}{|c|c|c|c|c|c|c|c|c|}
\hline \multirow[b]{2}{*}{ Country } & \multicolumn{8}{|c|}{ Age groups } \\
\hline & $\begin{array}{l}\text { Time period } \\
\text { (reference) }\end{array}$ & All ages & $\begin{array}{c}\text { Five years or } \\
\text { younger }\end{array}$ & $\begin{array}{c}\text { Five to } 14 \\
\text { years }\end{array}$ & 15 to 64 years & $\begin{array}{l}65 \text { years or } \\
\text { older }\end{array}$ & $\begin{array}{l}75 \text { years or } \\
\text { older }\end{array}$ & $\begin{array}{l}85 \text { years or } \\
\text { older }\end{array}$ \\
\hline Finland & 1985 to $1992(4)$ & - & - & - & 6.2 & 27.1 & 35.8 & 44.5 \\
\hline Finland & 1985 to 1989 (8) & - & 24.2 & 8.9 & - & - & - & - \\
\hline Denmark & 1989 to 1994 (1) & - & 13 to 23 & - & - & 27 to $55^{*}$ & - & - \\
\hline \multirow[t]{2}{*}{ France $^{+}$} & 1991 to 1995 (5) & 8.3 & 15.2 to 16.9 & 1.5 to 3 & 4.2 to 5.7 & 22.5 to 28.3 & - & 0 \\
\hline & $1996(6)$ & 8.3 & 12 & - & - & 29 & - & 70 \\
\hline Sweden & 1964 to $1980(2)$ & 6.1 & - & - & - & 40 to 47 & - & - \\
\hline \multirow[t]{4}{*}{ Finland } & & & $<2$ years & $\leq 16$ years & & & & \\
\hline & 1983 to 1992 (9) & - & 53 & 10.5 & - & - & - & - \\
\hline & $1993(9)$ & - & 70 & 20 & - & - & - & - \\
\hline & $1994(9)$ & - & 110 & 30 & & & & - \\
\hline Belgium & 1983 to $1994(10)$ & 8.3 & - & - & - & - & - & - \\
\hline \multirow{4}{*}{$\begin{array}{l}\text { England and } \\
\text { Wales }\end{array}$} & & & $<1$ year & & & & & \\
\hline & $1982(7)$ & 4.1 & 14 & - & - & - & 12 & - \\
\hline & $1986(7)$ & - & 18 & - & - & - & 14 & - \\
\hline & $1992(7)$ & 8.7 & 34 & - & - & - & 36 & - \\
\hline
\end{tabular}

*Older than 60 years of age; ${ }^{+}$Bacteremia and meningitis with bacteremia

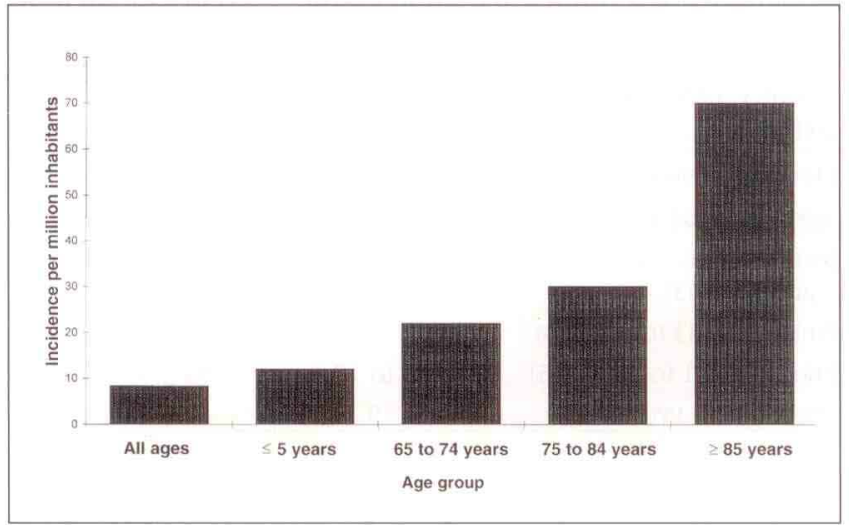

Figure 1) Streptococcus pneumoniae bacteremia incidence per 1,000,000 inhabitants in France by age group. Data from reference 5

per year (range 0.6/100,000 in England-Wales to 2.1/100,000 for Asians living in the North East Thames region of England [14]). Children have an increased incidence of pneumococcal meningitis (8); children younger than six months of age have an incidence rate of $7.1 / 100,000$, children younger than one year $6.8 / 100,000$, children younger than two years $4.7 / 100,000$, children younger than five years $2.1 / 100,000$, and children younger than $161 / 100,000$ (the adult rate). Since the Haemophilus influenzae type b vaccine came into widespread use, pneumococcus has become the leading cause of purulent meningitis in France (Figure 3), as in other countries. In adults, the incidence increases beginning at age 65 years $(5,7)$. As with septicemia, the sex ratio favours men in all European countries.

Serotype distribution varies from one country to the next or from one year to the next, but $85 \%$ to $95 \%$ are contained in the 23 -valent vaccine. In France, $85.6 \%$ of serotypes are contained in a heptavalent vaccine conjugate for meningitis (15).

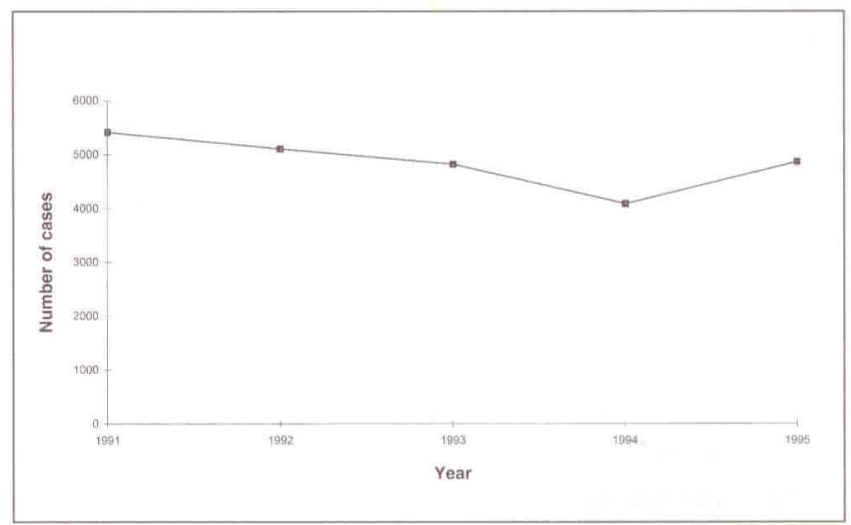

Figure 2) Streptococcus pneumoniae bacteremia in France from 1991 to 1995. Data from reference 5

Pneumonia: Pneumococcal pneumonia is considered the leading cause of community-acquired pneumonia (16), even though the diagnosis may not be definitive. This contrasts with invasive infections, where the diagnosis is made after isolation of pneumococcus from a normally sterile site, mainly blood and cerebrospinal fluid. Incidence rates vary according to the diagnostic method used (eg, blood culture, protected bronchial sampling with or without brushing, bronchial aspiration, expectoration, indirect methods such as pneumolysin antibody testing or testing for antigens in urine, serum or expectoration). This leads to great variation in the results of epidemiological studies. The difficulty is heightened by the poor performance of diagnostic tests; approximately $50 \%$ of pneumonias have a definite microbiological diagnosis. Incidence can be assessed by prospective studies $(17,18,19)$ or from discharge codes (code 480 to 486 , International Classification of Disease [of World Health Organization-9]) for patients hospitalized in institutions taking in the majority of patients for a 
TABLE 3

Incidence of pneumococcal meningitis

\begin{tabular}{|c|c|c|c|c|}
\hline Country, author (reference) & Year & Incidence per 100,000 & Vaccine coverage & Mortality rate $(\%)$ \\
\hline \multicolumn{5}{|l|}{ Sweden } \\
\hline Burman (2) & 1964 to 1980 & 1.4 & - & 33 \\
\hline Berg et al (35) & 1987 to 1989 & 1.2 & 100 & 24 \\
\hline Kragsbjerg et al (36) & 1981 to 1992 & 1 & 96.4 & 16 \\
\hline England (North East Thames Region) & & 0.8 (Caucasians) & 90 & 22 \\
\hline Urwin et al (14) & 1990 to 1993 & 2.1 (Asians) & & \\
\hline \multicolumn{5}{|l|}{ Wales and England } \\
\hline Aszkensay et al (7) & 1982 to 1992 & 0.6 & - & - \\
\hline \multicolumn{5}{|l|}{ Finland } \\
\hline Sanklampen et al (4) (> 16 years) & 1983 to 1993 & 0.9 & 95 & - \\
\hline \multirow[t]{5}{*}{ Eskola et al $(8)(<16$ years $)$} & 1985 to 1995 & 7.1 (<6 months) & & \\
\hline & & $2.1(<5$ years $)$ & & \\
\hline & & $6.8(<1$ year $)$ & & \\
\hline & & 1 (< 16 years) & & \\
\hline & & $4.7(<2$ years $)$ & & \\
\hline \multicolumn{5}{|l|}{ France } \\
\hline Mehl-Auget (6) & 1991 to 1995 & 0.86 to 1.10 & $85.6^{*}$ & 25 \\
\hline
\end{tabular}

*With a heptavalent vaccine conjugate

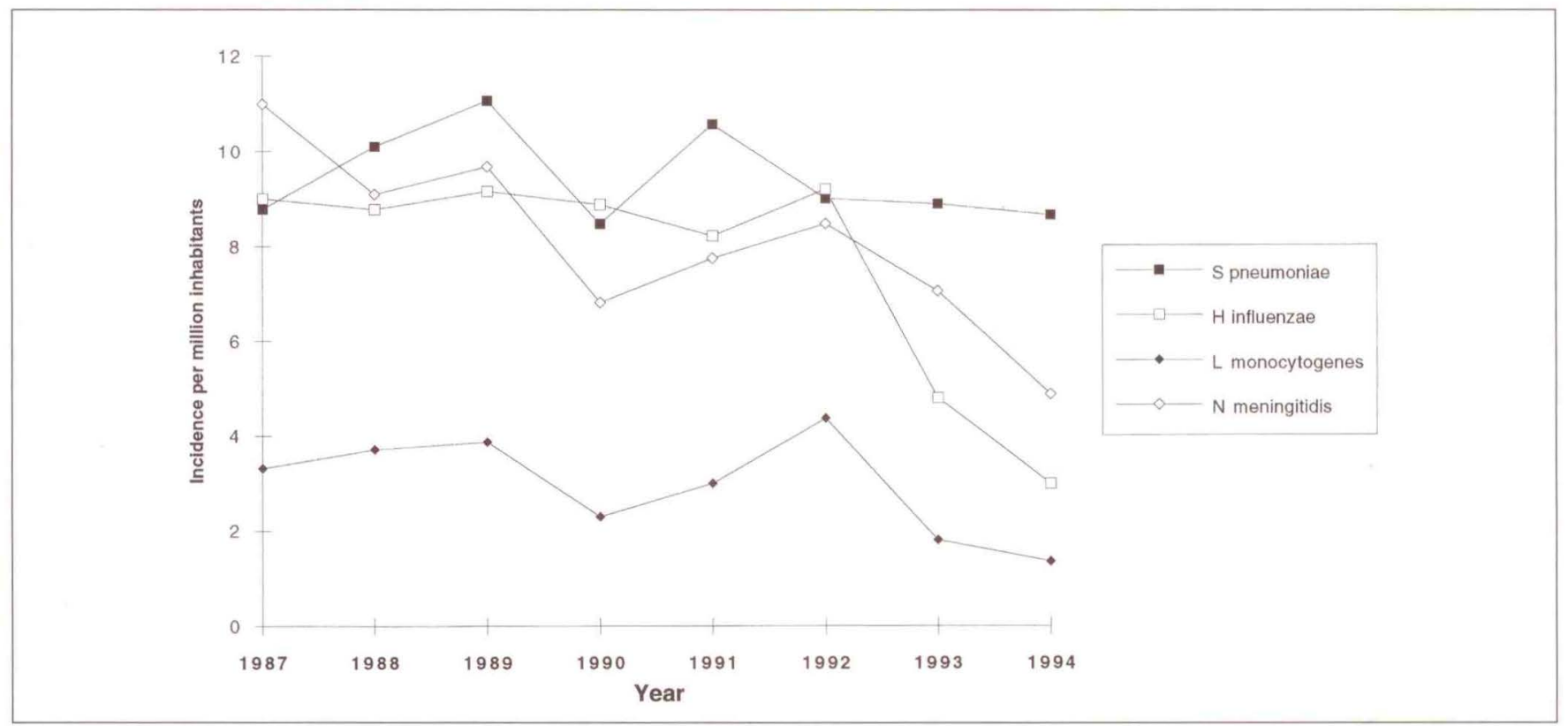

Figure 3) Bacterial meningitis in France from 1987 to 1995. Data from reference 5. S pneumoniae Streptococcus pneumoniae; H influenzae Haemophilus influenze; L monocytogenes Listeria monocytogenes; $\mathrm{N}$ meningitidis Neissera meningitidis

given population $(20,21)$. Pneumococcal infections can be calculated on the basis of specific groups of patients to whom ratios found in the literature are applied $(20,21)$. For example, at least $80 \%$ of pneumococcal-positive blood cultures are associated with pneumonia; $5 \%$ to $30 \%$ ( $15 \%$ to $20 \%$ in general) of pneumococcal pneumonia is accompanied by a positive blood culture. Therefore, it is possible to determine the approximate number of cases of pneumococcal pneumonia hospitalized per year if the number of cases septicemia in that country correlated to the population is known.

Table 4 (17-23) summarizes the rare studies of pneumonia incidence. There is a great variation in the data concerning pneumonia of all etiologies combined; in particular, the inci- dence in England is low (the methodology in this study did not include chest X-rays) (17). The Finnish studies were based on clinical and radiological criteria $(18,19)$. The French study was based in part on pneumonia diagnoses in hospital, which generally included an x-ray on admission (20). In those patients older than 60 to 65 years of age, the incidence rate rises significantly.

The incidence of pneumonia increases with age (Figure 4), especially beginning at age 60 years, as found in Finland, Holland and France. In general, pneumonia-related mortality also varies according to age, as well as out-patient ( $3 \%$ on average) or in-patient ( $9 \%$ on average; more than $25 \%$ in bacteremicassociated cases) management. Pneumococcus is rarely spon- 
TABLE 4

Incidence per 100,000 inhabitants per year of communityacquired pneumonia*

\begin{tabular}{|c|c|c|c|c|}
\hline \multirow[b]{2}{*}{$\begin{array}{l}\text { Country, year } \\
\text { (reference) }\end{array}$} & \multicolumn{2}{|c|}{ All etiologies } & \multicolumn{2}{|c|}{ Pneumococcal } \\
\hline & $\begin{array}{c}\text { Global } \\
\text { incidence }\end{array}$ & $\begin{array}{c}\text { In- } \\
\text { patients }\end{array}$ & $\begin{array}{l}\text { Global } \\
\text { incidence }\end{array}$ & $\begin{array}{c}\text { In- } \\
\text { patients }\end{array}$ \\
\hline \multicolumn{5}{|l|}{ Great Britain } \\
\hline $1987(17)^{\dagger}$ & 470 & 103 & $169^{+}$ & \\
\hline \multicolumn{5}{|l|}{ Sweden } \\
\hline $1987(22)$ & 1000 & & - & \\
\hline \multicolumn{5}{|l|}{ Finland } \\
\hline $1982(18)$ & 1160 & 540 & $300^{\S}$ & $126^{5}$ \\
\hline 1982 to $1984(19)$ & $1150^{\prime}$ & $700^{1}$ & 220 & \\
\hline \multicolumn{5}{|l|}{ France } \\
\hline 1995 to 1996 (20) & 795 & $168\left(550^{\circ}\right)$ & 252 & $50\left(220^{\sharp}\right)$ \\
\hline \multicolumn{5}{|l|}{ Spain } \\
\hline $1983(23)$ & & 77 & & \\
\hline \multicolumn{5}{|l|}{ Holland } \\
\hline $1991(21)^{* * *}$ & - & & 137 & $23\left(202^{\natural)}\right)$ \\
\hline
\end{tabular}

*Some data are calculated from the genuine data in the article; ${ }^{+}$Patients 16 years of age or older; ${ }^{*} 36 \%$ were diagnosed by blood or other cultures, or antigen detection; $\$ 30 \%$ of etiologies assumed to be pneumococcal (data calculated, not cited in article); "Patients older than 60 years of age; **Patients older 50 years of age

taneously declared as the etiological agent associated with death; of 15,840 pneumonia deaths in France in 1995, only $2.8 \%$ were pneumococcal origin as indicated on the death certificate. Ninety-five per cent of the deaths occurred after age 60 years; $45 \%$ were in the 80 to 89 year age group (20). The incidence of pneumococcal pneumonia was higher in cases of comorbidity (19\% compared with 4\% [24]). In western Europe as a whole, Fedson et al (11) estimates the annual number of hospitalized cases of pneumonia of all etiologies combined to be 575,300 in subjects older than 65 years of age. Pneumococcus was found to be responsible for 172,590 to 287,650 cases. The annual number of deaths was found to be 76,500 (11).

\section{EPIDEMIOLOGY OF RESISTANCE}

Antimicrobial-resistant Streptococcus pneumoniae is a genuine pandemic. Resistance varies widely from one country to another in Europe. It is very high in Spain (greater than $40 \%$ ) and France (greater than $40 \%$ in 1996), and rare in northern Europe. Table $5(15,25-32)$ summarizes the data on the differences, with surprisingly diametrically opposed rates for countries bordering each other such as Belgium and France. Antibiotic prescribing habits definitely play a major role, in particular the overconsumption of antibiotics in young children (over $60 \%$ of pneumococcal otitis cases in France are resistant to penicillin). Resistance to macrolides varies from one country to another; it was low in Spain when pneumococcus with reduced susceptibility to penicillin emerged (31) but was already higher in France (greater than 25\%) (15). The increase in resistance to macrolides in Belgium parallels an increase in the consumption of this family of antibiotics (27). The low incidence in Italy is apparently due to the preference for intravenous administration of cephalosporins (29). The resistant strains consist mainly of serotypes $23,6,9$ and 14 in most countries. Epidemic strains, such as strain 23, have been described in Spain, Iceland and the United States.

The very common resistance in meningeal and ear, nose and throat infections is becoming increasingly frequent in France, about $30 \%$ for septicemia and pneumonia $(15,33)$. The

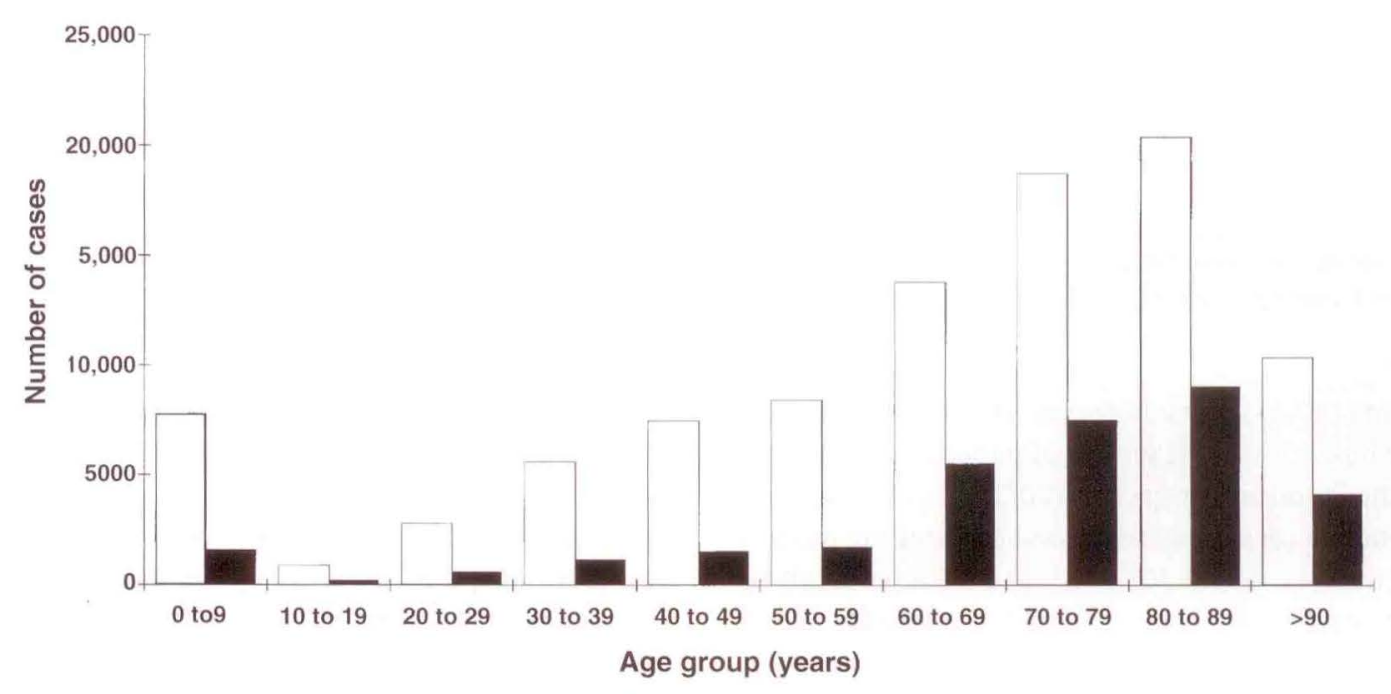

$\square$ all cases $\mathbf{S}$ pneumoniae

Figure 4) Annual incidence of all cases of community-acquired pneumonia and suspected pneumococcal pneumonia in France by age group. Data from reference 20; S pneumoniae Streptococcus pneumoniae 
Percentage of resistance

\begin{tabular}{|c|c|c|c|c|c|}
\hline Country (reference) & $\begin{array}{l}\text { Number of } \\
\text { strains }\end{array}$ & Years & $\begin{array}{l}\text { Percentage reduced } \\
\text { susceptibility to } \\
\text { penicillin or resistant }\end{array}$ & $\begin{array}{l}\text { Percentage resistant } \\
\text { to macrolides }\end{array}$ & $\begin{array}{l}\text { Pneumococcal serotypes with } \\
\text { reduced susceptibility to penicillin }\end{array}$ \\
\hline \multirow[t]{3}{*}{ France (15) } & 825 & 1984 & 0.5 & 18.9 & \\
\hline & 1470 & 1990 & 12 & 26.2 & $23 \mathrm{E}, 14,6 \mathrm{~V}, 19,9 \mathrm{~B}$ \\
\hline & 4078 & 1996 & 42.8 & 51.2 & $23,14,9,6,19,15$ \\
\hline \multirow[t]{2}{*}{ England and Wales (25) } & 544 & 1990 & 1.5 & 2.8 & $23 \mathrm{~F}, 6 \mathrm{~B}, 9 \mathrm{~B}$ \\
\hline & 583 & 1995 & 3.9 & 8.6 & $9 \mathrm{~V}, 6 \mathrm{~B}, 19 \mathrm{~A}, \mathrm{C}$ and $\mathrm{F}, 23 \mathrm{~F}$ \\
\hline Sweden (26) & 500 & 1990 & 0.002 & - & - \\
\hline \multirow[t]{3}{*}{ Belgium (27) } & 301 & 1984 & 0 & - (less than $5 \%$ ) & \\
\hline & 540 & 1990 & 4.1 & 17 & \\
\hline & 641 & 1993 & 2.3 & 21.5 & $23,19,14,9,15$ \\
\hline Holland (28) & - & 1995 to 1996 & 1.1 & - & $14,20,19,9,15$ \\
\hline Germany (30) & 110 & 1992 to 1994 & 4 & - & - \\
\hline Italy (29) & 312 & 1993 & 5.5 & 3.8 & - \\
\hline Spain (31) & $\begin{array}{l}68 \\
85\end{array}$ & $\begin{array}{l}1984 \\
1990\end{array}$ & $\begin{array}{l}11.7 \\
60.0\end{array}$ & $\begin{array}{l}2.9 \\
9.4\end{array}$ & - \\
\hline Switzerland (32) & 351 & 1993 to 1994 & 7 & 6 & $6,7,19,14,1$ \\
\hline
\end{tabular}

constant, gradual development of resistance in countries such as Spain and France, and Hungary and Poland (34) suggests that resistance will spread to neighbouring countries.

\section{CONCLUSIONS}

Invasive pneumococcal infections are a genuine public health problem in Europe because of their frequency and the development of multiple antibiotic resistance. Unfortunately, they are not notifiable diseases, and their epidemiology is not known in a uniform, accurate way. Rates of invasive infections are comparable in different countries; the average rate is $10 / 100,000$, of which approximately $1 / 100,000$ are meningitis. The average figures hide disparities from one country to another, with an increase reported in the northern European countries, Denmark in particular. They also hide the bimodal distribution with a high rate before the age of two years, especially for meningitis, and an increasing rate in persons older than 65 years of age, in a quasilinear fashion. The data regarding pneumonia are more disparate, but all point to the prominence of pneumococcus, a large number of hospitalizations and a mortality rate (about $10 \%$ ). The heaviest toll is in persons older than 60 years of age, particularly those over 80 years of age.

The epidemiology of resistance is distributed unevenly and is disturbing because of its rate. The high level of resistance in France or Spain leads to the fear that this situation is irreversible as history has shown for the resistance of Staphylococcus aureus to penicillin. Just beginning in other countries, resistance must be surveyed regarding the risk of increase in the future. Awareness of this epidemiology definitely implies that a policy for antibiotic use, in particular in children, and a vaccination policy with perhaps, in the future, the eradication of the carriage of multiresistant strains through vaccination with a conjugate vaccine, could be a hope (37). In the meantime, vaccine prevention must remain or become a major objective.

\section{REFERENCES}

1. Nielsen SV, Henrichsen J. Incidence of invasive pneumococcal disease and distribution for capsular type for pneumococci in Denmark, 1989/94. Epidemiol Infect 1996;117:411-6.

2. Burman LA. Invasive pneumococcal infections: incidence, predisposing factors and prognosis. Rev Infect Dis 1985;7:133-42.

3. Hedlund J, Svenson SB, Kalin M, et al. Incidence, capsular types and antibiotic susceptibility of invasive Streptococcus pneumoniae in Sweden. Clin Infect Dis 1995;21:948-53.

4. Sankinlampi U, Herva E, Haikola R, et al. Epidemiology of invasive Streptococcus pneumoniae infections in adults in Finland. Epidemiol Infect 1997;118:7-15.

5. Mehl-Auget I, Vaillant V, Goulet V. Surveillance des méningites et des bactériémies à: $H$ influenzae, $N$ menigitidis, $S$ pneumoniae, $L$ monocytogenes, $S$ agalatiae, $S$ pyogenes. Saint Maurice: Réseau National de Santé Public (EPIBAC). 1997:1-71.

6. Annual epidemiological report. Infectious Diseases epidemiology in France in 1996. Saint Maurice: Réseau National de Santé Public (EPIBAC), 1997.

7. Aszkenasy OM, George RC, Begg NT. Pneumococcal bacteraemia and meningitis in England and Wales. Commun Dis Rep CDR Rev 1995;5:R45-9.

8. Eskola J, Takala AK, Kela E, Pekkanen E, Kalliokoski R, Leinonen M. Epidemiology for invasive pneumococcal infections in children in Finland. JAMA 1992;268:3323-7.

9. Baer M, Vuento R, Vesikari T. Increase in bacteraemic pneumococcal infections in children. Lancet 1995;345:661. (Lett)

10. Ducoffre G. Surveillance des Maladies Infectieuses par un réseau de laboratoires de microbiologie. Bruxelles: Institut d'Hygiène et d'Epidémiologie, 1996.

11. Fedson D, Musker D, Eskola J. Pneumococcal vaccine. In: Plotkin 
SA, Orenstein WA, eds. Vaccines, 3rd edn. Philadelphia: WB Saunders. (In press)

12. Giesecke J, Fredland H. Increase in pneumococcal bacteraemia in Sweden. Lancet 1997;699:700. (Lett)

13. Källenius G, Hedlund J, Svenson SB, Kalin M, Henrichsen J. Pneumococcal bacteraemia in Sweden. Lancet 1997;349:1910. (Lett)

14. Urwin G, Yuan MF, Chall LM. Pneumococcal meningitis in the North East Thames Region UK: epidemiology and molecular analysis of isolates. Epidemiol Infect 1996;117:95-102.

15. Geslin P, Fremaux A. Sissia G, Spicq C. [Streptococcus pneumoniae: serotypes, invasive and antibiotic resistant strains. Current situation in France]. Presse Med 1998;27(Suppl 1):21-7.

16. Marrie TJ. Community-acquired pneumonia. Clin Infect Dis 1994;18:501-15.

17. Woodhead MA, MacFarlane JT. Prospective study of the aetiology and outcome of pneumonia in the community. Lancet 1987;i:671-4.

18. Jokinen C, Heiskanen L, Juvonen $\mathrm{H}$, et al. Incidence of community-acquired pneumonia in the population of four municipalities in Eastern Finland. Am J Epidemiol 1993;137:977-88.

19. Koivula I, Sten M, Mäkolä P. Risk factors for pneumonia in the elderly. Am J Med 1994;96:313-20.

20. Gaillat J. [Epidemiology of systemic Streptococcus pneumoniae infections]. Presse Med 1998;27(Suppl 1):9-16.

21. Baltussen R, Ament A, Leidi RM, et al. Cost effectiveness of vaccination against pneumococcal pneumonia in the Netherlands. Eur J Public Health 1997; 7:153-61.

22. Hedlund $\mathrm{J}$. Community-acquired pneumonia requiring hospitalization. Stockolm: Kongl carolinska Medico Chirurciska Institutet, 1995.

23. Telenti A. Estudio epidmiologico multicentrico sobre neumonis en Espana. Med Clin 1983;80(Suppl 1):11-26.

24. Koivula I, Sten M, Leinonen M, Makela PH. Clinical efficacy of peumococcal vaccine in the elderly: a randomized, single-blind population-based trial. Am J Med 1997;103:281-90.

25. Johnson AP, Speller DC, George RC, Warner M, Domingue G, Efstratiou A. Prevalence of antibiotic resistance and serotypes in pneumococci in England and Wales: results of observational surveys in 1990 and 1995. BMJ 1996;312:1454-6.

26. Olsson-Liljequist B, Burman LG, Kallings I. Antibiotic susceptibility of upper respiratory tract pathogens in Sweden: a seven year follow-up study including loracarbef. Swedish Respiratory Tract Study Group. Scand J Infect Dis 1992:24:485-93.

27. Verhaegen J, Glupczynski Y, Verbist L, et al. Capsular types and antibiotic sensitivity of pneumococci isolated from patients with serious infections, 1980-1993. Clin Infect Dis 1995;20:1339-45.

28. Hermans PW, Sluijter M, Elzenaar K, et al. Penicillin-resistant Streptococcus pneumoniae in the Netherlands: results of a 1-year molecular epidemiologic survey. J Infect Dis 1997;175:1413-22.

29. Marchese A, Debbia EA, Arvigo A, Pesce A, Schito GC. Susceptibility of Streptococcus pneumoniae strains isolated in Italy to penicillin and ten other antibiotics. J Antimicrob Chemother 1995;36:833-7.

30. Goldstein FW, Acar JF. Antimicrobial resistance among lower respiratory tract isolates of Streptococcus pneumoniae: results of a 1992-93 western Europe and USA collaborative surveillance study. The Alexander Project Collaborative Group. J Antimicrob Chemother 1996;38(Suppl A):71-84.

31. Linaeres I, Pallares rr. Alonso T, et al. Trends in antimicrobial resistance of clinical isolates of Streptococcus pneumoniae in Bellvitge Hospital, Barecelona, Spain (1979-1990). Clin Infect Dis 1992;15:99-105.

32. Wüst J, Huf E, Kayser FH. Antimicrobial susceptibilities and serotypes of invasive Streptococcus pneumoniae strains in Switzerland. I Clin Microbiol 1995;33:3159-63.

33. Pallares R, Linares J, Vadillo M, et al. Resistance to penicillin and cephalosporin and mortality from severe pneumococcal pneumoniae in Barcelona, Spain. N Engl J Med 1995;33:474-80.

34. Privitera G. Penicillin resistance among Streptococcus pneumoniae in Europe. Diagn Microbiol Infect Dis $1994 ; 19: 157-61$

35. Berg S, Trollfors B, Claesson BA, et al. Incidence and prognosis of meningitis due to Haemophilus influenzae, Streptococcus pneumoniae and Neisseria meningitidis in Sweden. Scand J Infect Dis 1996;28:247-52.

36. Kragsbjerg P, Källman J, Olcen P. Pneumococcal meningitis in adults. Scand J Infect Dis 1994;26:659-66.

37. Dagan R, Melamed R, Muallem M, et al. Reduction of nasopharyngeal carriage of pneumococci during the second year of life by a heptovalent conjugate pneumococcal vaccin. J Infect Dis 1996;174:1271-8. 


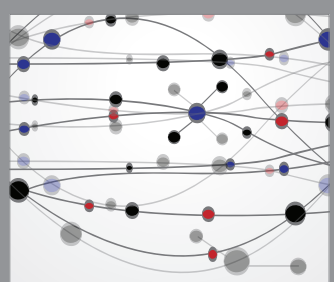

The Scientific World Journal
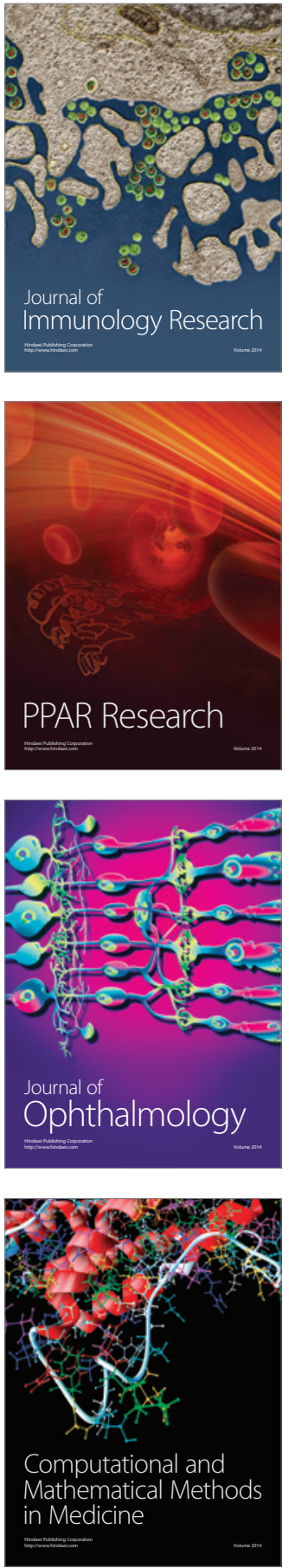

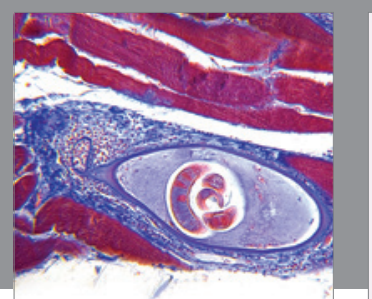

Gastroenterology Research and Practice

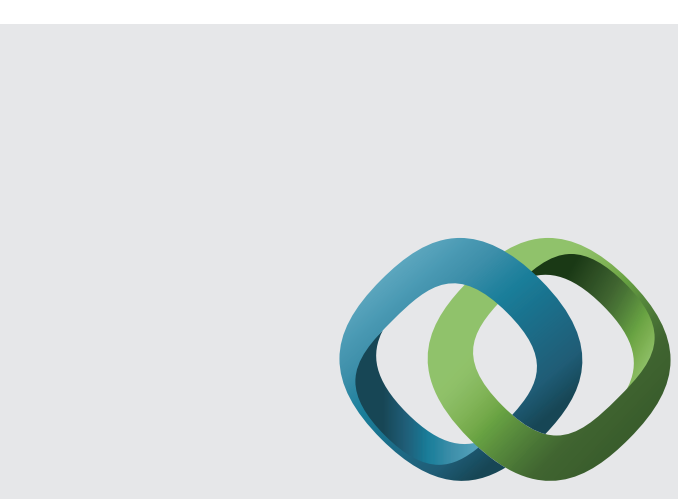

\section{Hindawi}

Submit your manuscripts at

http://www.hindawi.com
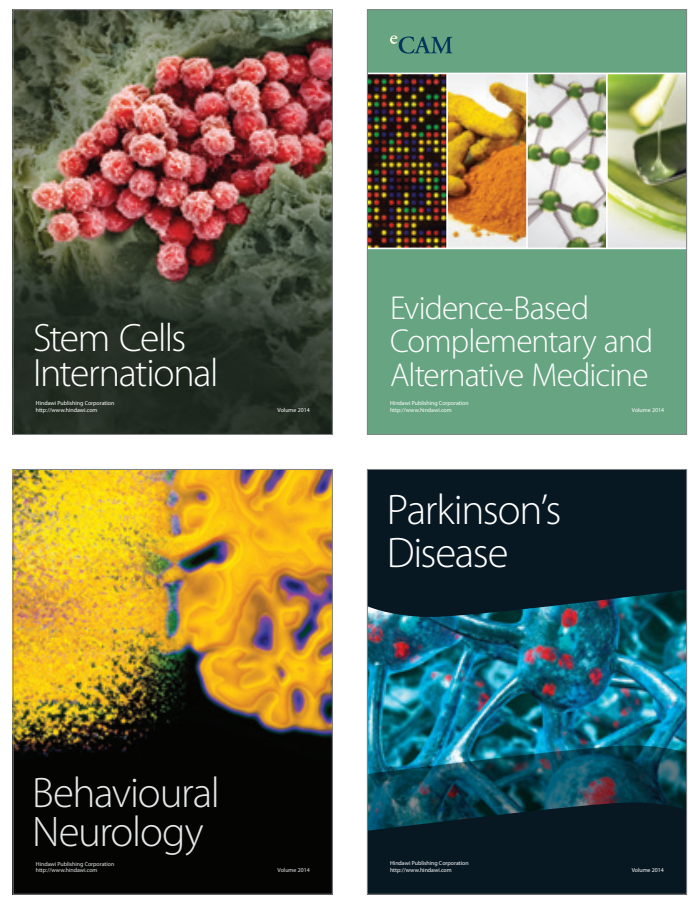
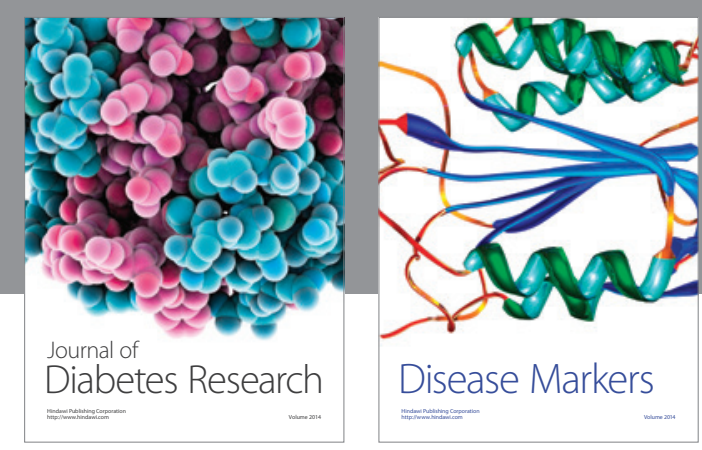

Disease Markers
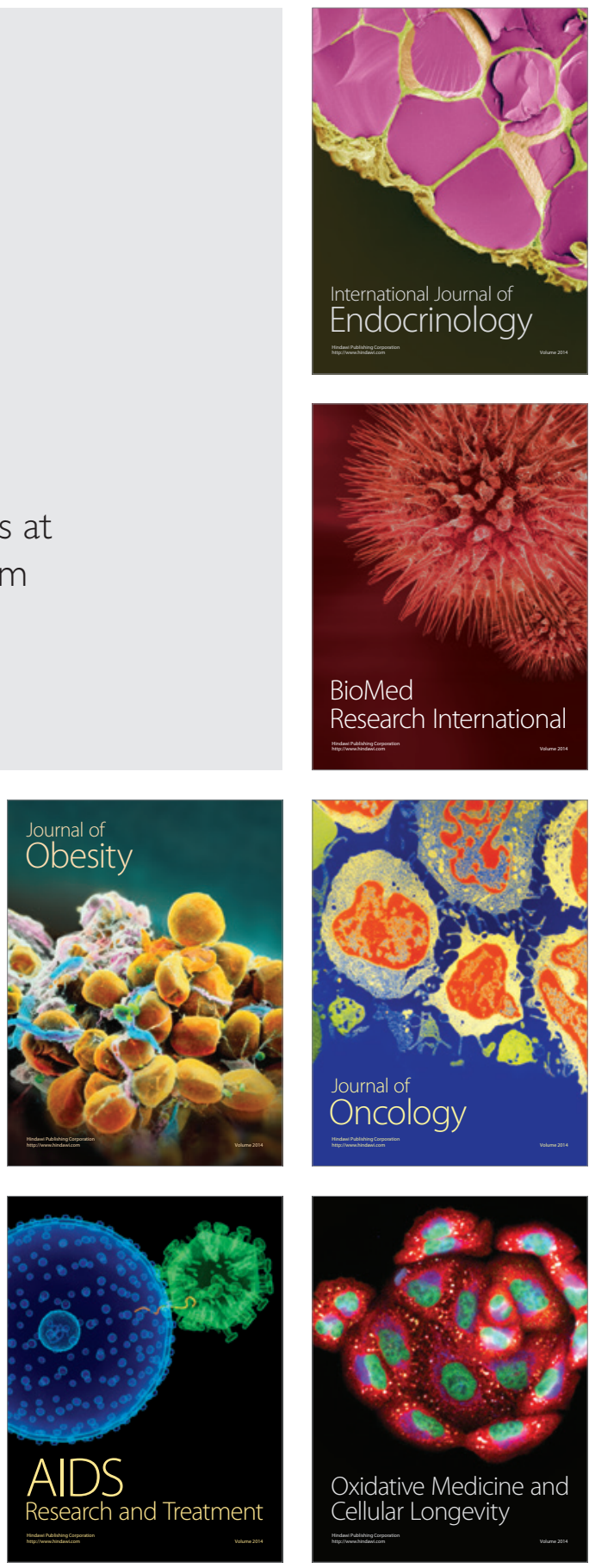